\title{
Immigration and Social Aspects of Sustainable Development. The Case of Germany
}

\section{Imigracja a społeczne aspekty zrównoważonego rozwoju. Przypadek Niemiec}

\author{
Paweł Rydzewski \\ Institute of Sociology, Faculty of Philosophy and Sociology \\ Maria Curie-Sktodowska University in Lublin, Poland \\ E-mail: p.rydzewski@umcs.pl
}

\begin{abstract}
The aim of the article is to show the relationship between immigration and the social aspect of sustainable development. Data from the German General Social Survey (ALLBUS) study conducted in 2016 on a sample of 3490 respondents (residents of Germany) was used. Research suggests that this relationship is negative: mass immigration from culturally foreign countries and social environments can significantly reduce the quality of life of residents in developed societies. This manifests in opinions about the need to limit or stop immigration. The case of Germany can probably be generalized to other developed countries, especially from the European Union.
\end{abstract}

Key words: sustainable development, immigration, ALLBUS, social opinion, Germany

\section{Streszczenie}

Celem artykułu jest ukazanie związku między imigracją i społecznym aspektem zrównoważonego rozwoju. Wykorzystano dane pochodzące z badań German General Social Survey (ALLBUS) przeprowadzonych w 2016 roku na próbie 3490 respondentów - mieszkańców Niemiec. Wyniki badań sugerują, że związek ten jest negatywny masowa imigracja z krajów i środowisk obcych kulturowo może znacząco obniżać jakość życia mieszkańców rozwiniętych społeczeństw. Przejawia się to w opiniach o konieczności ograniczenia lub zatrzymania imigracji. Przypadek Niemiec może być prawdopodobnie uogólniony na inne kraje rozwinięte, zwłaszcza z Unii Europejskiej.

Słowa kluczowe: rozwój zrównoważony, imigracja, ALLBUS, opinia społeczna, Niemcy

\section{Introduction}

In what way is immigration linked with the social aspects of sustainable development? First, let us start with the definition of social sustainability. Social sustainability can be described as a state in which participants in social life enjoy a sufficiently high quality of life resulting from a combination of various specific factors. As Robert Prescott-Allen puts it, human wellbeing is a condition in which all members of society are able to determine and meet their needs and have a large range of choices and opportunities to fulfil their potential (Prescott-Allen, 2001, p. 13). Immigration can improve the quality of peo- ple's life, giving them the opportunity to meet representatives of other cultures, broaden their cultural horizons, or learn about other types of behaviour. On the other hand, it can also reduce the quality of life if it creates a sense of threat and results in social tensions. This all depends on what social environment immigrants come to and what is their social background.

Immigration is by no means a new phenomenon in Europe. In recent years, however, its size and social impact have been greater than ever before, giving rise to a new term 'migration crisis'. The problem of growing immigration is probably best seen in Germany and that is why I would like to consider the case of Germany in this article. 
The migration crisis has sparked lively political debates throughout Germany, revealing polarized attitudes towards immigration. Only in 2015, about 890,000 people migrated to Germany, marking the biggest migration crisis since World War II. In 2015, for the first time more than 1.2 million people applied for asylum in the EU Member States, with Germany being their first destination. This unprecedented arrival of so many asylum seekers and immigrants revealed divergent views on how to deal with the migration crisis and on what influence it could have on German society (Sola, 2015, p. 2-6). This crisis was characterized by a seemingly unstoppable influx of asylum seekers and migrants who were perceived as culturally more distinct than those who had arrived in the past (Dustmann et al., 2017, p. 497$550)$.

Tensions between different religious, racial and ethnic groups increased in 2016. The most striking change since 2011 is the growing number of people who started to perceive tensions between religious groups (this number increased from $28 \%$ in 2011 to $38 \%$ in 2016). Also the percentage of people reporting high tensions between racial and ethnic groups increased from $37 \%$ in 2011 to $41 \%$ in 2016 . Countries where high tensions between religious groups were reported more frequently than the EU average include Austria, Belgium, France, Germany, Italy, the Netherlands and the United Kingdom. This is connected with Muslim immigration (and debates on this immigration) (Ahrendt et al., 2016, p. 86).

How important is the immigration issue to German people? As shown by studies carried out in 8 European countries ${ }^{1}$, the most important problem in these countries between 2010 and 2017 was unemployment (often combined with the country's economic situation or issues such as rising prices, inflation, cost of living or health and social security). Only in Germany, immigration was indicated as the most important issue throughout the entire observation period (while in Turkey people were most concerned about terrorism in the first place and then about unemployment) (Glorius, 2018, p. 14).

Our main research question is: What is the relationship between immigration and the social aspect of sustainable development?

\section{Methodology}

The data used in this article comes from the research carried out as part of the German General Social Survey program, which was implemented in 2016 on a sample of 3490 respondents.

The German General Social Survey (ALLBUS / GGSS) is a national social program in Germany, which is similar to the American General Social Sur-

1 Germany, Finland, Italy, Greece, Spain, Bulgaria, Hungary and Turkey. vey (GSS). The sample was drawn from all persons (German and non-German) who resided in private households and were born before 1 January 1998. Two stage disproportionate random sample in Western Germany and Eastern Germany was used. In the first sample stage, municipalities (Gemeinden) in Western Germany and municipalities in Eastern Germany were selected with a probability proportional to their number of adult residents; in the second sample stage, individual persons were selected at random from the municipal registers of residents. Targeted individuals who did not have adequate knowledge of German to conduct the interview were treated as systematic unit non-responses. The data was collected on the basis of personal, oral interviews with a standardized questionnaire (CAPI - Computer Assisted Personal Interviewing) and two additional self-completion questionnaires (CASI - Computer Assisted Self-Interviewing) for ISSP (split questionnaire design). ${ }^{2}$ In total, 589 variables were used in the study. The questionnaire used in the study included, among others, questions about immigration. Researchers were interested in opinions of German residents on different immigrant groups. These opinions were expressed on a 3-level scale (immigration should not be restricted, immigration should be restricted, immigration should be stopped). The following immigrant groups were taken into account: ethnic Germans from Eastern Europe, asylum seekers, workers from EU-countries, workers from non-EU-countries (from countries in Europe that are not the EU members), war refugees, political refugees, economic migrants, EU-workers from Eastern Europe, EU-workers from other countries, workers not from the EUcountry, spouses and kids of immigrants.

\section{Results}

First, we will analyse opinions on different immigrant groups, which were expressed by choosing one of the three possible answers: immigration of a given group should not be restricted, immigration of this group should be restricted, and immigration of this group should be stopped. Responses were dichotomised into two groups: immigration should not be restricted and immigration should be restricted or stopped. Responses from the second group, i.e. that immigration should be restricted or stopped, were counted.

Table 1 shows the distribution of opinions concerning different immigrant groups. The opinion that immigration should be restricted or stopped is most often expressed in relation to economic migrants (approx. 50\%) and non-EU workers (approx. 47\%). Such opinion is the least often expressed about workers from EU countries (approx 28\%). 
Table 1. Opinions on restricting immigration of different immigrant groups ${ }^{3}$

\begin{tabular}{|c|c|c|c|}
\hline \multirow{2}{*}{ IMMIGRANT GROUPS } & \multicolumn{2}{|c|}{ Responses } & \multirow[b]{2}{*}{ Percent of cases } \\
\hline & $\mathrm{N}$ & Percent & \\
\hline Ethnic Germans from Eastern Europe & 1023 & $8.1 \%$ & $33.1 \%$ \\
\hline Asylum seekers & 1234 & $9.7 \%$ & $40.0 \%$ \\
\hline Workers from Eu-Countries & 866 & $6.8 \%$ & $28.0 \%$ \\
\hline Workers from non-Eu-Countries & 1295 & $10.2 \%$ & $41.9 \%$ \\
\hline War refugees & 995 & $7.8 \%$ & $32.2 \%$ \\
\hline Political refugees & 1008 & $8.0 \%$ & $32.6 \%$ \\
\hline Economic migrants & 1549 & $12.2 \%$ & $50.2 \%$ \\
\hline Eu-workers - Eastern Europe & 1246 & $9.8 \%$ & $40.3 \%$ \\
\hline Eu-workers - Other & 1057 & $8.3 \%$ & $34.2 \%$ \\
\hline Workers not from Eu-country & 1456 & $11.5 \%$ & $47.2 \%$ \\
\hline Spouses, kids of immigrants & 949 & $7.5 \%$ & $30.7 \%$ \\
\hline Total & 12678 & $100.0 \%$ & $410.6 \%$ \\
\hline
\end{tabular}

Table 2. Opinions on restricting immigration by region of residence

\begin{tabular}{|c|c|c|c|c|}
\hline \multirow{2}{*}{\multicolumn{2}{|c|}{ IMMIGRANT GROUPS }} & \multicolumn{2}{|c|}{ REGION } & \multirow{3}{*}{$\frac{\text { Total }}{1023}$} \\
\hline & & \multirow{2}{*}{$\begin{array}{c}\text { West } \\
659\end{array}$} & \multirow{2}{*}{$\begin{array}{c}\text { East } \\
364\end{array}$} & \\
\hline Ethnic Germans from Eastern Europe & $\mathrm{N}$ & & & \\
\hline & $\%$ & $32.8 \%$ & $33.8 \%$ & \\
\hline \multirow[t]{2}{*}{ Asylum seekers } & $\mathrm{N}$ & 788 & 446 & 1234 \\
\hline & $\%$ & $39.2 \%$ & $41.4 \%$ & \\
\hline \multirow[t]{2}{*}{ Workers from Eu-countries } & $\mathrm{N}$ & 537 & 329 & 866 \\
\hline & $\%$ & $26.7 \%$ & $30.5 \%$ & \\
\hline \multirow[t]{2}{*}{ Workers from non-Eu-countries } & $\mathrm{N}$ & 844 & 451 & 1295 \\
\hline & $\%$ & $42.0 \%$ & $41.8 \%$ & \\
\hline \multirow[t]{2}{*}{ War refugees } & $\mathrm{N}$ & 584 & 411 & 995 \\
\hline & $\%$ & $29.1 \%$ & $38.1 \%$ & \\
\hline \multirow[t]{2}{*}{ Political refugees } & $\mathrm{N}$ & 595 & 413 & 1008 \\
\hline & $\%$ & $29.6 \%$ & $38.3 \%$ & \\
\hline \multirow[t]{2}{*}{ Economic migrants } & $\mathrm{N}$ & 989 & 560 & 1549 \\
\hline & $\%$ & $49.2 \%$ & $51.9 \%$ & \\
\hline \multirow[t]{2}{*}{ Eu-workers - Eastern Europe } & $\mathrm{N}$ & 790 & 456 & 1246 \\
\hline & $\%$ & $39.3 \%$ & $42.3 \%$ & \\
\hline \multirow[t]{2}{*}{ Eu-workers - other } & $\mathrm{N}$ & 642 & 415 & 1057 \\
\hline & $\%$ & $31.9 \%$ & $38.5 \%$ & \\
\hline \multirow[t]{2}{*}{ Workers not from Eu-country } & $\mathrm{N}$ & 938 & 518 & 1456 \\
\hline & $\%$ & $46.7 \%$ & $48.1 \%$ & \\
\hline \multirow[t]{2}{*}{ Spouses, kids of immigrants } & $\mathrm{N}$ & 552 & 397 & 949 \\
\hline & $\%$ & $27.5 \%$ & $36.8 \%$ & \\
\hline Total & $\mathrm{N}$ & 2010 & 1078 & 3088 \\
\hline
\end{tabular}

These opinions depended on the region of residence (western vs. eastern Länder, Table 2), education and age (Tables $3 \& 4$ ).

Residents of Eastern Germany are generally more restrictive in their attitudes to immigration of almost all immigrant groups than those living in Western Germany. These differences are most pronounced in opinions regarding war refugees and political refugees, as well as families of immigrants (approx. 37$38 \%$ compared to $28-30 \%$ ).

Opinions on immigration differ greatly depending on respondents' education: people with low education vs. those with high education. These differences are both quantitative (up to even a dozen or more percent) and widespread (concerning most groups of immigrants). German residents with a low level of education are much more likely than those with high education to be in favour of limiting or stopping immigration of workers from EU-countries (approx. $34 \%$ compared to approx. $21 \%$ ), war refugees and political refugees (approx. 40-41\% compared to approx. 26\%), ethnic Germans from Eastern Europe, spouses, kids of immigrants and EU-workers other than from Eastern Europe (36-38\% compared to 26$29 \%$ ), and EU-workers from Eastern Europe (approx. $45 \%$ compared to approx. $35 \%$ ). 
Table 3. Opinions on restricting immigration by education level

\begin{tabular}{|c|c|c|c|c|c|}
\hline \multirow{2}{*}{\multicolumn{2}{|c|}{ IMMIGRANT GROUPS }} & \multicolumn{3}{|c|}{ EDUCATION } & \multirow{3}{*}{$\begin{array}{l}\text { Total } \\
1016 \\
\end{array}$} \\
\hline & & \multirow{2}{*}{\begin{tabular}{|l} 
Low \\
300 \\
\end{tabular}} & \multirow{2}{*}{$\begin{array}{c}\text { Intermediate } \\
418\end{array}$} & \multirow{2}{*}{\begin{tabular}{|l|} 
High \\
298 \\
\end{tabular}} & \\
\hline Ethnic Germans from Eastern Europe & $\mathrm{N}$ & & & & \\
\hline & $\%$ & $36.2 \%$ & $36.8 \%$ & $27.1 \%$ & \\
\hline \multirow[t]{2}{*}{ Asylum seekers } & $\mathrm{N}$ & 347 & 491 & 386 & 1224 \\
\hline & $\%$ & $41.9 \%$ & $43.3 \%$ & $35.1 \%$ & \\
\hline \multirow[t]{2}{*}{ Workers from Eu-countries } & $\mathrm{N}$ & 280 & 352 & 228 & 860 \\
\hline & $\%$ & $33.8 \%$ & $31.0 \%$ & $20.7 \%$ & \\
\hline \multirow[t]{2}{*}{ Workers from non-Eu-countries } & $\mathrm{N}$ & 355 & 490 & 437 & 1282 \\
\hline & $\%$ & $42.8 \%$ & $43.2 \%$ & $39.8 \%$ & \\
\hline \multirow[t]{2}{*}{ War refugees } & $\mathrm{N}$ & 329 & 378 & 281 & 988 \\
\hline & $\%$ & $39.7 \%$ & $33.3 \%$ & $25.6 \%$ & \\
\hline \multirow[t]{2}{*}{ Political refugees } & $\mathrm{N}$ & 342 & 377 & 285 & 1004 \\
\hline & $\%$ & $41.3 \%$ & $33.2 \%$ & $25.9 \%$ & \\
\hline \multirow[t]{2}{*}{ Economic migrants } & $\mathrm{N}$ & 429 & 557 & 552 & 1538 \\
\hline & $\%$ & $51.7 \%$ & $49.1 \%$ & $50.2 \%$ & \\
\hline \multirow[t]{2}{*}{ Eu-workers - Eastern Europe } & $\mathrm{N}$ & 375 & 477 & 386 & 1238 \\
\hline & $\%$ & $45.2 \%$ & $42.0 \%$ & $35.1 \%$ & \\
\hline \multirow[t]{2}{*}{ Eu-workers - other } & $\mathrm{N}$ & 314 & 419 & 316 & 1049 \\
\hline & $\%$ & $37.9 \%$ & $36.9 \%$ & $28.8 \%$ & \\
\hline \multirow[t]{2}{*}{ Workers not from Eu-country } & $\mathrm{N}$ & 414 & 525 & 506 & 1445 \\
\hline & $\%$ & $49.9 \%$ & $46.3 \%$ & $46.0 \%$ & \\
\hline \multirow[t]{2}{*}{ Spouses, kids of immigrants } & $\mathrm{N}$ & 300 & 360 & 286 & 946 \\
\hline & $\%$ & $36.2 \%$ & $31.7 \%$ & $26.0 \%$ & \\
\hline Total & $\mathrm{N}$ & 829 & 1135 & 1099 & 3063 \\
\hline
\end{tabular}

Table 4. Opinions on restricting immigration by age category

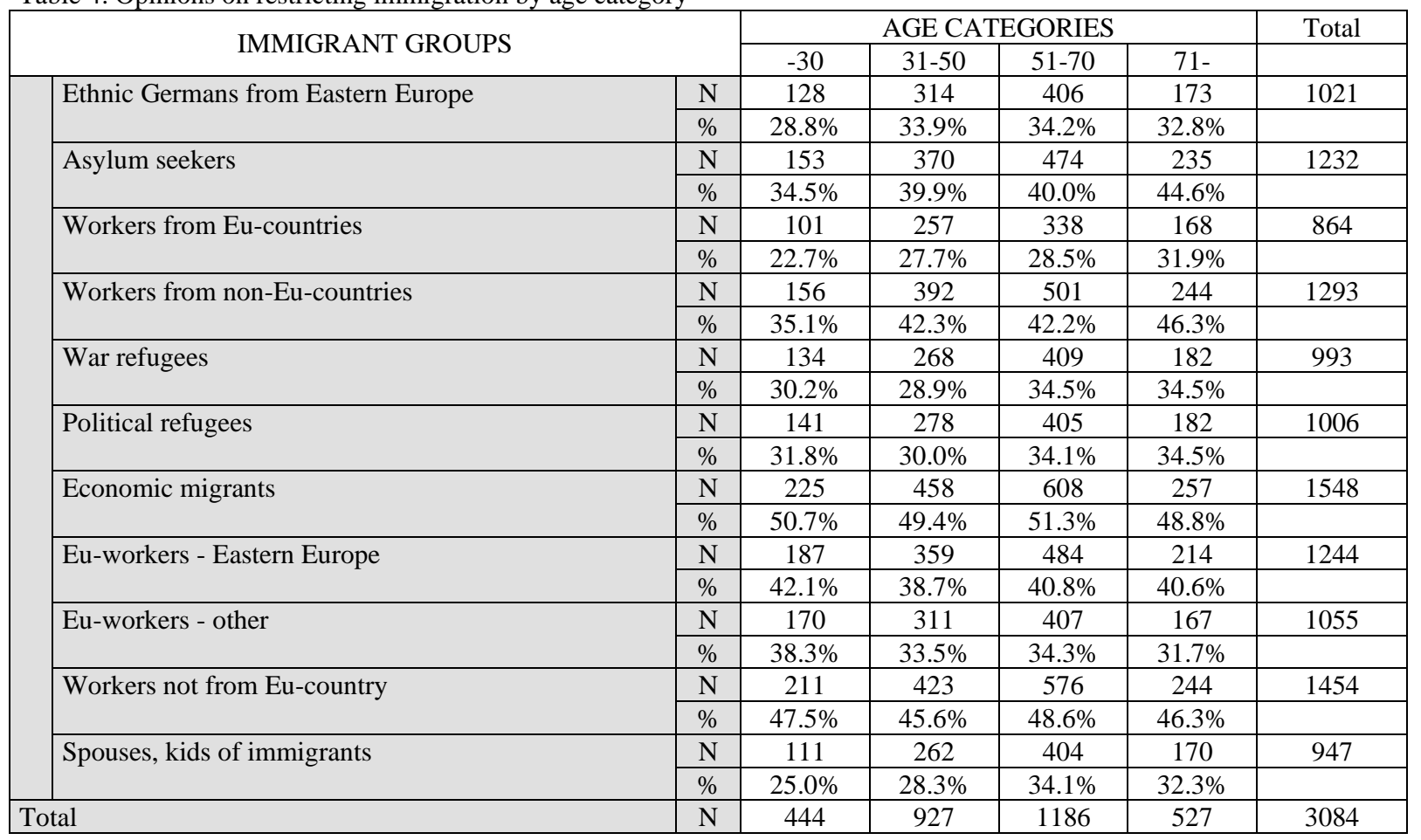

tive opinions (immigration of these groups should be restricted or stopped) increases with the age of respondents. In relation to asylum seekers, this percentage increases from approx. $35 \%$ in the category of respondents up to 30 years old, to approx. $45 \%$ in the group of respondents over 71 years old. The situation is very much similar in the case of workers from non-EU-countries (an increase from approx. $35 \%$ to approx. $46 \%)$.
When it comes to workers from EU-countries, this percentage of restrictive opinions increases with the age of respondents from approx. 23\% to approx. $32 \%$. The rise in negative attitudes towards immigration of spouses and kids of immigrants is slightly smaller, but still noticeable (from approx. 25\% to approx. $32 \%$ ). In several other cases, this rise can also be noted, but it is not so considerable. 
Table 5. Opinions on immigration of asylum seekers by age category

\begin{tabular}{|c|c|c|c|c|c|c|}
\hline \multirow{2}{*}{\multicolumn{2}{|c|}{ ASYLUM SEEKERS IMMIGRATION }} & \multicolumn{4}{|c|}{ AGE CATEGORIES } & \multirow{3}{*}{$\frac{\text { Total }}{344}$} \\
\hline & & \multirow{2}{*}{$\begin{array}{c}-30 \\
76\end{array}$} & \multirow{2}{*}{$\begin{array}{c}31-50 \\
122\end{array}$} & \multirow{2}{*}{$\begin{array}{c}51-70 \\
112\end{array}$} & \multirow{2}{*}{$\begin{array}{l}71- \\
34\end{array}$} & \\
\hline Should be unrestricted & $\mathrm{N}$ & & & & & \\
\hline & $\%$ & $33.2 \%$ & $24.8 \%$ & $19.1 \%$ & $12.6 \%$ & $21.8 \%$ \\
\hline \multirow[t]{2}{*}{ Should be restricted } & $\mathrm{N}$ & 138 & 342 & 428 & 216 & 1124 \\
\hline & $\%$ & $60.3 \%$ & $69.5 \%$ & $73.0 \%$ & $80.3 \%$ & $71.3 \%$ \\
\hline \multirow[t]{2}{*}{ Stop completely } & $\mathrm{N}$ & 15 & 28 & 46 & 19 & 108 \\
\hline & $\%$ & $6.6 \%$ & $5.7 \%$ & $7.8 \%$ & $7.1 \%$ & $6.9 \%$ \\
\hline \multirow[t]{2}{*}{ Total } & $\mathrm{N}$ & 229 & 492 & 586 & 269 & 1576 \\
\hline & $\%$ & $100.0 \%$ & $100.0 \%$ & $100.0 \%$ & $100.0 \%$ & $100.0 \%$ \\
\hline
\end{tabular}

Gamma $\mathrm{p}<0,0005$

Table 6. Opinions on immigration of asylum seekers by education level

\begin{tabular}{|c|c|c|c|c|c|}
\hline \multirow{2}{*}{\multicolumn{2}{|c|}{ ASYLUM SEEKERS IMMIGRATION }} & \multicolumn{3}{|c|}{ EDUCATION } & \multirow{3}{*}{$\begin{array}{c}\text { Total } \\
335\end{array}$} \\
\hline & & \multirow{2}{*}{$\begin{array}{c}\text { Low } \\
47\end{array}$} & \multirow{2}{*}{$\begin{array}{c}\text { Intermediate } \\
86\end{array}$} & \multirow{2}{*}{\begin{tabular}{|c|} 
High \\
202
\end{tabular}} & \\
\hline Should be unrestricted & $\mathrm{N}$ & & & & \\
\hline & $\%$ & $11.9 \%$ & $14.9 \%$ & $34.4 \%$ & $21.5 \%$ \\
\hline \multirow[t]{2}{*}{ Should be restricted } & $\mathrm{N}$ & 292 & 452 & 372 & 1116 \\
\hline & $\%$ & $74.1 \%$ & $78.3 \%$ & $63.3 \%$ & $71.6 \%$ \\
\hline \multirow[t]{2}{*}{ Stop completely } & $\mathrm{N}$ & 55 & 39 & 14 & 108 \\
\hline & $\%$ & $14.0 \%$ & $6.8 \%$ & $2.4 \%$ & $6.9 \%$ \\
\hline \multirow[t]{2}{*}{ Total } & $\mathrm{N}$ & 394 & 577 & 588 & 1559 \\
\hline & $\%$ & $100.0 \%$ & $100.0 \%$ & $100.0 \%$ & $100.0 \%$ \\
\hline
\end{tabular}

Gamma $\mathrm{p}<0,0005$

Table 7. Opinions on immigration of asylum seekers by region of residence

\begin{tabular}{|c|c|c|c|c|}
\hline \multirow{2}{*}{\multicolumn{2}{|c|}{ ASYLUM SEEKERS IMMIGRATION }} & \multicolumn{2}{|c|}{ REGION } & \multirow[b]{2}{*}{ Total } \\
\hline & & West & East & \\
\hline \multirow[t]{2}{*}{ Should be unrestricted } & $\mathrm{N}$ & 254 & 90 & 344 \\
\hline & $\%$ & $24.4 \%$ & $16.8 \%$ & $21.8 \%$ \\
\hline \multirow[t]{2}{*}{ Should be restricted } & $\mathrm{N}$ & 720 & 406 & 1126 \\
\hline & $\%$ & $69.1 \%$ & $75.7 \%$ & $71.4 \%$ \\
\hline \multirow[t]{2}{*}{ Stop completely } & $\mathrm{N}$ & 68 & 40 & 108 \\
\hline & $\%$ & $6.5 \%$ & $7.5 \%$ & $6.8 \%$ \\
\hline \multirow[t]{2}{*}{ Total } & $\mathrm{N}$ & 1042 & 536 & 1578 \\
\hline & $\%$ & $100.0 \%$ & $100.0 \%$ & $100.0 \%$ \\
\hline
\end{tabular}

Chi-squared $\mathrm{p}=0,002$

Let us now take a closer look at the opinions about asylum seekers and war refugees, i.e. those immigrants who are, on the one hand, most in danger in their homelands, and on the other hand, are typically the most culturally distinct (Table 5).

Although only about $7 \%$ of German residents believe that immigration of this group should be stopped completely and generally there are no significant differences in this respect depending on the respondents' age, in total approx. $71 \%$ of German residents believe that immigration of such people should be limited. This varies depending on age approx. $80 \%$ of the eldest German residents (over 71 years) hold this opinion; while in the group of the youngest respondents (up to 30 years old), this percentage is noticeably lower (approx. 60\%).

The influence of education on the opinions about immigration of asylum seekers is even more visible (Table 6). Only about $12 \%$ of people with low education believe that immigration of asylum seekers should not be restricted; this percentage increases to approx. $15 \%$ in the group of respondents with intermediate education and up to approx. $34 \%$ in the group with high education. Analogically, the percentage of people who believe that immigration of asylum seekers should be limited decreases with education, with a clear dividing line between those with higher education (approx. 63\%) and those without higher education (approx. 74-78\%). Respondents with low education are most likely to express the view that immigration of asylum seekers should be stopped (approx. 14\%), those with intermediate education are less likely to hold this opinion (approx. $7 \%$ ), whereas people with higher education are the least likely to believe that immigration of asylum seekers should be stopped (approx. 2\%).

The region of residence has some bearing on people's opinions about immigration of asylum seekers, but its influence is not as significant as that of age and education (Table 7). Residents of Eastern Germany are slightly more likely to favour limiting this migration than those of Western Germany (approx. 76\% compared to approx. 69\%).

When it comes to immigration of war refugees (Table 8 ), only approx. $4 \%$ of Germans would like to see this immigration stopped, while approx. $56 \%$ would 
Table 8. Opinions on immigration of war refugees by age category

\begin{tabular}{|c|c|c|c|c|c|c|}
\hline \multirow{2}{*}{\multicolumn{2}{|c|}{ WAR REFUGEES IMMIGRATION }} & \multicolumn{4}{|c|}{ AGE CATEGORIES } & \multirow[b]{2}{*}{ Total } \\
\hline & & -30 & $31-50$ & $51-70$ & $71-$ & \\
\hline \multirow[t]{2}{*}{ Should be unrestricted } & $\mathrm{N}$ & 134 & 221 & 228 & 88 & 671 \\
\hline & $\%$ & $50.0 \%$ & $45.2 \%$ & $35.8 \%$ & $32.6 \%$ & $40.3 \%$ \\
\hline \multirow[t]{2}{*}{ Should be restricted } & $\mathrm{N}$ & 119 & 249 & 391 & 171 & 930 \\
\hline & $\%$ & $44.4 \%$ & $50.9 \%$ & $61.4 \%$ & $63.3 \%$ & $55.9 \%$ \\
\hline \multirow[t]{2}{*}{ Stop completely } & $\mathrm{N}$ & 15 & 19 & 18 & 11 & 63 \\
\hline & $\%$ & $5.6 \%$ & $3.9 \%$ & $2.8 \%$ & $4.1 \%$ & $3.8 \%$ \\
\hline \multirow[t]{2}{*}{ Total } & $\mathrm{N}$ & 268 & 489 & 637 & 270 & 1664 \\
\hline & $\%$ & $100.0 \%$ & $100.0 \%$ & $100.0 \%$ & $100.0 \%$ & $100.0 \%$ \\
\hline
\end{tabular}

Gamma p <0,0005

Table 9. Opinions on immigration of war refugees by education level

\begin{tabular}{|c|c|c|c|c|c|}
\hline \multirow{2}{*}{\multicolumn{2}{|c|}{ WAR REFUGEES IMMIGRATION }} & \multicolumn{3}{|c|}{ EDUCATION } & \multirow{3}{*}{$\begin{array}{c}\text { Total } \\
664 \\
\end{array}$} \\
\hline & & \multirow{2}{*}{$\begin{array}{c}\text { Low } \\
117 \\
\end{array}$} & \multirow{2}{*}{ Intermediate } & \multirow{2}{*}{$\begin{array}{c}\text { High } \\
336\end{array}$} & \\
\hline Should be unrestricted & $\mathrm{N}$ & & & & \\
\hline & $\%$ & $26.2 \%$ & $35.8 \%$ & $54.5 \%$ & $40.2 \%$ \\
\hline \multirow[t]{2}{*}{ Should be restricted } & $\mathrm{N}$ & 298 & 354 & 273 & 925 \\
\hline & $\%$ & $66.8 \%$ & $60.1 \%$ & $44.2 \%$ & $56.0 \%$ \\
\hline \multirow[t]{2}{*}{ Stop completely } & $\mathrm{N}$ & 31 & 24 & 8 & 63 \\
\hline & $\%$ & $7.0 \%$ & $4.1 \%$ & $1.3 \%$ & $3.8 \%$ \\
\hline \multirow[t]{2}{*}{ Total } & $\mathrm{N}$ & 446 & 589 & 617 & 1652 \\
\hline & $\%$ & $100.0 \%$ & $100.0 \%$ & $100.0 \%$ & $100.0 \%$ \\
\hline
\end{tabular}

Gamma $\mathrm{p}<0,0005$

Table 10. Opinions on immigration of war refugees by region of residence

\begin{tabular}{|c|c|c|c|c|}
\hline \multirow{2}{*}{\multicolumn{2}{|c|}{ WAR REFUGEES IMMIGRATION }} & \multicolumn{2}{|c|}{ REGION } & \multirow[b]{2}{*}{ Total } \\
\hline & & West & East & \\
\hline \multirow[t]{2}{*}{ Should be unrestricted } & $\mathrm{N}$ & 489 & 182 & 671 \\
\hline & $\%$ & $45.6 \%$ & $30.7 \%$ & $40.3 \%$ \\
\hline \multirow[t]{2}{*}{ Should be restricted } & $\mathrm{N}$ & 556 & 376 & 932 \\
\hline & $\%$ & $51.8 \%$ & $63.4 \%$ & $55.9 \%$ \\
\hline \multirow[t]{2}{*}{ Stop completely } & $\mathrm{N}$ & 28 & 35 & 63 \\
\hline & $\%$ & $2.6 \%$ & $5.9 \%$ & $3.8 \%$ \\
\hline \multirow[t]{2}{*}{ Total } & $\mathrm{N}$ & 1073 & 593 & 1666 \\
\hline & $\%$ & $100.0 \%$ & $100.0 \%$ & $100.0 \%$ \\
\hline
\end{tabular}

Chi-squared $\mathrm{p}<0,0005$

like to have some restrictions put on this immigration. The opinions depend on the age of respondents: the percentage of people who think that immigration should not be reduced decreases with age (from approx. 50\% in the youngest group, to approx. $33 \%$ in the group of older respondents). On the other hand, the percentage of people who believe that this migration should be restricted increases with age (approx. 44\% and approx. 63\%, respectively). Age has little influence on the opinion that immigration of war refugees should be stopped completely.

Likewise, when education of respondents is taken into account, the opinion that immigration of war refugees should not be restricted is expressed by approx. 55\% of people with higher education, approx. $36 \%$ of those with intermediate education and approx. $26 \%$ of those with low education (Table 9). Similarly, the percentage of German residents who believe that immigration of war refugees should be restricted decreases with education level (from ap- prox. $67 \%$ of people with low education, to approx. $44 \%$ of people with high education). Approx. $7 \%$ of people with low education and only approx. $1 \%$ of those with high education would like to stop immigration of war refugees (however, this data should be interpreted carefully given small numbers of the dependent variable in this category).

Opinions on immigration of war refugees differ significantly depending on the region of residence. Approx. $6 \%$ of inhabitants of Eastern Germany and less than $3 \%$ of those living in the western part would like to stop this immigration completely (Table 10). The opinion that immigration of war refugees should be restricted is expressed by approx. 63\% of residents of Eastern Germany and approx. 52\% of those living in Western Germany. Germans living in the western part are more likely to believe that immigration of war refugees should not be restricted than those from the eastern part (approx. 46\% and approx. 31\%, respectively). 


\section{Conclusions}

Opinions of German residents on policy towards immigrants are divided. Approximately $30-40 \%$ of them are in favour of restricting or stopping immigration, but views on this issue depend on the type of immigration. The opinion that immigration should be restricted or stopped is most often expressed in relation to economic migrants and non-EU workers (approx. 50\%). Such opinion is most rarely formulated when it comes to workers from the EU (approximately $28 \%$ ). It is also worth noting that opinions on restricting or stopping immigration of people particularly vulnerable to persecution (war refugees and asylum seekers) are not markedly different than opinions on immigration of other groups, and they stand at $32-40 \%$. In other words, German residents are more likely to accept workers from the EU countries than those who come from outside the EU, and they are generally more likely to accept immigration of workers than immigration of refugees and asylum seekers.

As can be seen, restrictive opinions are more likely to be expressed by people living in Eastern Germany, with a low level of education and by elderly people; i.e. by those whose social position and frequently economic situation is potentially worse. On the other hand, immigration is favoured most often by young, well-educated people from Western Germany.

As already mentioned, I was particularly interested in groups of immigrants that are most at risk in their homelands, i.e. asylum seekers and war refugees. Approx. $71 \%$ of German residents believe that immigration of asylum seekers should be limited (with $7 \%$ of them believing that it should be stopped completely). When the attitudes towards war refugees are considered, approx. $60 \%$ of Germans think that this immigration should be limited (with approx. $4 \%$ believing that it should be stopped completely).

German residents are more likely to accept immigration of people who come from countries that are culturally and politically closer to Germany and those who can fill in the gaps in the labour market, than immigration from culturally and politically distant regions, even if this immigration is motivated by threat. This may be partly explained by pragmatic attitude and partly by negative perception of immigrants, being a result of personal experiences or the image presented in the media, which may give rise to a sense of danger.

To answer the key question about the relationship between immigration and the social aspect of sustainable development (measured mainly at the level of life quality), it must be stated that the available data suggests that this relationship is negative if there is a significant increase in the number of immigrants and if they come from environments and countries that are culturally different from their destination country. This conclusion that is formulated about the situation in Germany can be generalised to other European Union countries, at the very least. The sense of threat associated with the type and size of immigration can significantly reduce the quality of life in developed societies.

\section{References}

1. AHRENDT D., ANDERSON R., DUBOIS H., JUNGBLUT J.-M., LEONČIKAS T., PÖNTINEN L., SANDOR E., 2017, Quality of life, quality of public services, and quality of society, Eurofound Publications Office of the European Union, Luxembourg, p. 86.

2. CEOBANU, A. M., ESCANDELL X., 2010, Comparative Analyses of Public Attitudes Toward Immigrants and Immigration Using Multinational Survey Data: A Review of Theories and Research, in: Annual Review of Sociology, 36, p. 309-328.

3. DUSTMANN, C., FASANI F., FRATTINI T., MINALE L., SCHNBERG U., 2017, On the Economics and Politics of Refugee Migration, in: Economic Policy, 32(91), p. 497-550.

4. DUSTMANN, C., PRESTON I., 2007, Racial and Economic Factors in Attitudes to Immigration, in: The B. E. Journal of Economic Analysis and Policy, 7, p. 1655-1655.

5. GLORIUS B., 2018, Public opinion on immigration and refugees and patterns of politicization. Evidence from the Eurobarometer, in: CEASEVAL Working Papers, WP/03-2018, p. 14.

6. HAINMUELLER, J., HOPKINS D., 2014, Public Attitudes toward Immigration, in: Annual Review of Political Science, 17, p. 225-249.

7. HATTON, T. J., 2017, Refugees and Asylum Seekers, the Crisis in Europe and the Future of Policy, in: Economic Policy, 32(91), p. 447-496.

8. HOLMBERG J., 1992, Making Development Sustainable: Redefining Institutions, Policy and Economics, Island Press, Washington.

9. O'ROURKE, K. H., SINNOTT R., 2006, The Determinants of Individual Attitudes Towards Immigration, in: European Journal of Political Economy, 22 (4), p. 838-861.

10. PRESCOTT-ALLEN R., 2001, The Wellbeing of Nations. A Country-by-Country Index of Quality of Life and the Environment, Island Press, Washington, Covelo, London, p. 13-14.

11. REED D. (ed.), 1997, Structural Adjustment, The Environment and Sustainable Development, Earthscan, London.

12. RUHS M., 2019, 'Migrants', 'Mobile Citizens' and the Borders of Exclusion in the European Union, in: Debating European Citizenship, ed. Bauböck R., IMISCOE Research Series. Springer, Cham.

13. SINGLETON, A, CARASSCO-HEIERMANN A., KIERANS D., 2016, Migration, Asylum and Refugees in Germany: Understanding the Data, IOM GMDAC Data Briefing Series, p. 1-6.

14. SOLA A., 2015, The 2015 Refugee Crisis in Germany: Concerns about Immigration and Populism, SOEP papers on Multidisciplinary Panel Data Research, Berlin 2018, p. 2. 
